removed. The operator did not find that the transducer encroached on the fontanelle nor did it impede his ability to perform the ventricular tap.

\section{Discussion}

Real-time ultrasound studies have shown that ventricular dilatation occurs in up to $40 \%$ of cases of intracranial haemorrhage during the neonatal period. ${ }^{2}$ Papile et $a l .{ }^{3}$ suggest that ventricular decompression by lumbar puncture may reduce the incidence of this condition. Decompression by the lumbar route, although obviously preferable, is not always possible due to basal arachnoiditis and cisternal obstruction. In this condition, noncommunication of CSF between the cerebral ventricles and the lumbar subarachnoid space precludes the use of lumbar puncture and direct ventricular taps may be necessary to remove CSF.

Lateral ventricular taps are a potentially dangerous procedure which should be undertaken only by experienced staff. Risks include infection, cyst formation, and damage to important areas within the brain. Intraventricular haemorrhage as a result of a ventricular tap has been reported. ${ }^{4}$ In order to minimise the risks of unnecessary iatrogenic problems by the needle passing through the ventricle, a method of performing ventricular taps under direct vision is described. No stereotactic method for needle insertion into the lateral ventricles has been previously reported. This method is simple and requires little ultrasound experience. The operator is given instructions on where the tip of the needle is in relation to the ventricle and insertion of the needle through the ventricle into the caudate nucleus can be avoided. Although the infant described here was fairly immature, it is likely that this procedure can be performed in most infants up to age 6 months, by which time progressive ossification of the skull prevents adequate visualisation of the ventricular system by ultrasonic methods.

\section{References}

1 Levene M I. Measurement of the growth of the lateral ventricles in preterm infants with real-time ultrasound. Arch Dis Child 1981; 56:900-4.

2 Levene M I, Starte D R. A longitudinal study of posthaemorrhagic ventricular dilatation in the newborn. Arch Dis Child 1981 ; 56: 905-10.

3 Papile L-A, Burstein J, Burstein R, Koffler H, Koops B L, Johnson J D. Posthemorrhagic hydrocephalus in lowbirthweight infants: treatment by serial lumbar punctures. J Pediatr 1980; 97: 273-7.

4 Pape K E, Wigglesworth J S. Haemorrhage, ischaemia, and the perinatal brain. London: Heinemann, 1979: 152.

Correspondence to Dr M I Levene, Department of Child Health, Leicester Royal Infirmary, Clinical Sciences Building, PO Box 65, Leicester LE2 7LX.

Received 22 April 1982

\title{
Congenital dislocation of the hip and short maternal stature
}

\section{AMITAI, A YAROM, R BLOCH, AND H POGRUND}

Department of Paediatrics and Department of Orthopaedics, Hadassah University Hospital, Mount Scopus, Jerusalem, Israel, and McMaster University Medical School, Hamilton, Ontario, Canada

SUMMARY The heights of 33 consecutively selected mothers of children in hospital for treatment of congenital dislocation of the hip ( $\mathrm{CDH})$ were compared with the heights of 54 mothers of children in hospital for conditions other than CDH. The mothers of the CDH children were found to be shorter than those of the control group by a mean of $4.4 \mathrm{~cm}$. This difference was statistically significant. Short maternal stature is associated with a narrow pelvis and presumably also with reduced uterine size which may cause restriction of space for the fetus.

The aetiology of congenital dislocation of the hip (CDH) has been the subject of numerous investigations and is still considered multifactorial. Several mechanical factors have been noted to correlate with $\mathrm{CDH}-$ such as breech presentation, ${ }^{1}$ increased birthweight and length, ${ }^{2}$ and a greater number of labours with fetopelvic disproportion. ${ }^{12}$ A restriction of space for the fetus in utero has also been suggested. ${ }^{3}$

Since maternal factors play an important role in affecting the available space for the fetus in utero and in view of the clinical observation that several mothers of children with $\mathrm{CDH}$ were short, we decided to investigate the association between maternal height and CDH.

\section{Patients and methods}

The subjects of this study were 33 infants and children with clinical and radiological evidence of 
CDH who had been consecutively admitted to our hospital during the period 1 January to 3 June 1981 with their mothers. Each patient had been examined and diagnosed as having $\mathrm{CDH}$ by a senior orthopaedic surgeon and was in hospital for traction or surgical correction of the condition. There were $7(21 \%)$ boys and $26(79 \%)$ girls. Thirty-one had been vertex presentations and 2 breech presentations at birth. The ages of the mothers ranged between 19 and 35 (mean of $26 \cdot 3$ ) years.

The control group comprised 54 infants and children who had been in hospital consecutively in the paediatric department between 1 April and 10 May 1981 with their mothers. Any patient who had CDH himself or in a sibling was excluded from the control group. The referral pattern of children with $\mathrm{CDH}$ was similar to that of other children.

The ethnic composition of the mothers in both groups is given in the Table. The height of each mother in each group was measured, and the difference between the mean heights of the two groups was assessed by the Student's $t$ test.

\section{Results}

Maternal height. The height of the mothers of the

Table Ethnic composition of mothers of patients with $C D H$ and mothers of control group

\begin{tabular}{lcclll}
\hline & \multicolumn{2}{c}{$C D H$ group } & & \multicolumn{2}{c}{ Control group } \\
\cline { 2 - 3 } \cline { 5 - 6 } \cline { 5 - 6 } & No & $\%$ & & No & $\%$ \\
\hline Ashkenazi jewish & 6 & $18 \cdot 2$ & & 13 & $24 \cdot 1$ \\
Sephardi jewish & 15 & $45 \cdot 4$ & & 22 & $40 \cdot 7$ \\
Arabic & 12 & $36 \cdot 4$ & & 19 & $35 \cdot 2$ \\
\hline
\end{tabular}

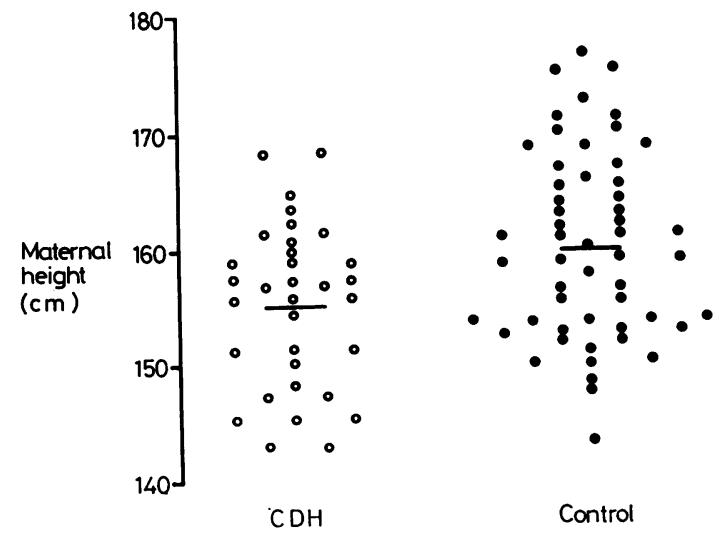

Figure Height of mothers of the $\mathrm{CDH}$ and control groups with mean height for both groups. patients with $\mathrm{CDH}$ ranged between 143 and 168, mean $( \pm$ SEM) $154 \cdot 8 \pm 1 \cdot 2 \mathrm{~cm}$. The height of the mothers in the control group ranged between 143 and 176 , mean $( \pm$ SEM $) 159 \cdot 2 \pm 1 \cdot 1 \mathrm{~cm}$. The difference between the means was $4.4 \mathrm{~cm}$ and was statistically significant $(P<0.01)$. The individual measurement of maternal height in both groups is given in the Figure.

\section{Discussion}

Mothers of children with $\mathrm{CDH}$ were significantly shorter than mothers in a control group. Since the referral pattern and the ethnic composition were similar in both groups, the two groups were comparable. Several features have been previously demonstrated in the aetiology of CDH. A high proportion of first born was present in several studies $^{24}$ and was related to the reduced stretching of the uterus in first pregnancies which increases the pressure on the fetus. ${ }^{4}$ An increased proportion of mechanical problems in labour, other than breech presentation, has also been noted. ${ }^{1}$ Fourteen per cent of mothers of infants with unstable hips and vertex presentation underwent caesarean section, compared with $8 \%$ of mothers of infants with stable hips and vertex presentation. The CDH group showed a higher prevalence of fetopelvic disproportion at birth compared with the overall population of children born at the same hospital. ${ }^{1}$ A narrow pelvis was shown to correlate with short stature ${ }^{5}$ and this possibly increases the chance of undergoing caesarean section.

In a thorough search we could find no data pertaining to the relationship of maternal height with $\mathrm{CDH}$. In this context it is interesting to note that the incidence of CDH is high in Japan compared with elsewhere $^{6}$ and the average stature of Japanese women is shorter than that of American and English women. ${ }^{7}$ Short maternal stature is probably correlated with decrease in fundal height and this might increase the pressure to which the fetus is exposed.

Other mechanical factors which act in the same way are increased birthweight and length of infants with $\mathrm{CDH}$ and increased prevalence of oligohydramnios in pregnancies of children with $\mathrm{CDH}^{8}$ This results again in limitation of space for the fetus in utero.

We found that mothers of children with $\mathrm{CDH}$ have significantly shorter stature than mothers in a control group. We suggest that short maternal stature is another possible aetiological factor in $\mathrm{CDH}$ and that offspring of mothers with very short stature should be considered at risk for the development of $\mathrm{CDH}$. 


\section{References}

1 Artz T D, Levine D B, Lim W N, Salvati E A, Wilson P D. Neonatal diagnosis, treatment, and related factors of congenital dislocation of the hip. Clin Orthop 1975; 110: 112-36.

2 Cyvin K B. Congenital dislocation of the hip joint. Clinical studies with special reference to the pathogenesis. Acta Paediatr Scand [Suppl] 1977; 263: 1-67.

3 Hensinger $R \mathbf{N}$. Congenital dislocation of the hip. Clinical Symposia, 31 January 1979, Ciba.

4 Dunn P M. Perinatal observations on the etiology of congenital dislocation of the hip. Clin Orthop 1976; 119: 11-22.

5 Clarke M F. Stature and hip width of young Indian women students of medicine and nursing. Hum Biol 1971; 43: $549-56$
6 Endo M, Iinuma TA, Umegaki Y, Tateno $Y$, Tanaka $H$, Tsuchiya K. Automated diagnosis of congenital dis location of the hip. Radiology 1977; 122: 25-30.

7 Heath B H, Hopkins C E, Miller C D. Physiques of Hawaii-born young men and women of Japanese ancestry, compared with college men and women of the United States and England. Am J Phys Anthropol 1961; 19: 173-84.

8 Dunn P M. Congenital deformation following premature rupture of the membranes (abstract). Teratology 1971; 4: 487.

Correspondence to Dr I Amitai, Paediatric Department, Hadassah University Hospital, Mount Scopus, POB 24035, Jerusalem 91240, Israel.

Received 19 May 1982

\title{
Congenital isolated thyrotrophin releasing hormone deficiency
}

\author{
H NIIMI, H INOMATA, N SASAKI, AND H NAKAJIMA \\ Department of Paediatrics, School of Medicine, Chiba University, Chiba, Japan
}

SUMMARY A $4 \frac{1}{3}$-year-old girl with congenital thyrotrophin-releasing hormone (TRH) deficiency is described. Oral TRH administration led to normal thyroid hormone and TRH levels in the blood; favourable growth and development was achieved.

Deficiency of thyroid-stimulating hormone (TSH) and hypothyroidism can occur in any condition that is associated with developmental defects of the pituitary or hypothalamus, or in children with idiopathic hypopituitarism. However isolated deficiency of TSH, or thyrotrophin-releasing hormone (TRH) is rare. ${ }^{12}$ We describe in detail a case of isolated TRH deficiency.

\section{Case report}

A $4 \frac{1}{3}$ year-old girl was referred to us because she was short.

She was the third child of healthy, intelligent parents. Pregnancy and delivery had been normal, as had been the neonatal period. Birthweight was $3200 \mathrm{~g}$ and length $50 \mathrm{~cm}$. Growth to age 1 year had apparently been normal but retardation of growth was noticed at 2-3 years of age.

Her parents were not related, but her maternal grandparents were consanguineous. There was no family history of thyroid disease, dwarfism, or mental abnormality.

Physical examinations showed height $93.0 \mathrm{~cm}$ $(-2.0 \mathrm{SD}$ of the mean height for Japanese girls as reported by the Japanese Ministry of Health and Welfare), weight $13.0 \mathrm{~kg}(-1.6 \mathrm{SD})$, with normal body proportions. The thyroid gland was not enlarged, and the remainder of the physical examina- tion was normal. Roentgenograms of the skull were normal and bone age was $2 \frac{3}{4}$ years.

Haematological studies, urine analysis, and blood chemical determinations were normal. An electroencephalogram was normal. Computerised tomography scans of the skull were normal. Her developmental quotient was estimated to be 112 .

At the initial visit, the serum thyroxine (T4) value was $4 \cdot 1 \mu \mathrm{g} / 100 \mathrm{ml}(52 \cdot 8 \mathrm{nmol} / \mathrm{l})$ (normal $4 \cdot 5-13 \cdot 5$ $\mu \mathrm{g} / 100 \mathrm{ml}$ ), serum tri-iodothyronine (T3) $177 \mathrm{ng} /$ $100 \mathrm{ml} \quad(2 \cdot 7 \mathrm{nmol} / \mathrm{l})$ (normal $98-202 \mathrm{ng} / 100 \mathrm{ml}$ ), and serum TSH $14 \mu \mathrm{U} / \mathrm{ml}$ (normal $<2-8$ ). Thyroid uptake of ${ }^{123}$ I sodium iodide was $7 \cdot 1 \%$ at 24 hours (normal 10-40\%). A thyroid scan gave normal results. Tests for antithyroglobulin antibody and antimicrosome antibody were negative. The serum thyroxine binding globulin determined by radioimmunoassay was $20 \cdot 3 \mu \mathrm{g} / \mathrm{ml}(338 \cdot 3 \mathrm{nmol} / \mathrm{l}$ ) (normal $15 \cdot 7-43 \cdot 3 \mu \mathrm{g} / \mathrm{ml})$.

A peak TSH level of $70 \mu \mathrm{U} / \mathrm{ml}$ was obtained after administration of $130 \mu \mathrm{g}(10 \mu \mathrm{g} / \mathrm{kg})$ of $\mathrm{TRH}$ intravenously (normal $10-40 \mu \mathrm{U} / \mathrm{ml}$ ). Two additional TRH tests showed similar positive responses. Luteinising hormone and follicle-stimulating hormone showed normal responses to intravenous injection of $40 \mu \mathrm{g}$ of luteinising hormone-releasing hormone. Serum growth hormone was demonstrable in the fasting state $(3 \cdot 2 \mathrm{ng} / \mathrm{ml})$, and an increase was obtained during insulin-induced hypoglycaemia $(20.5 \mathrm{ng} / \mathrm{ml})$. The plasma level of adrenocorticotrophin was $16 \mathrm{pg} / \mathrm{ml}$ (normal 15-85) in the early morning and a peak level of $27 \mathrm{pg} / \mathrm{ml}$ was obtained by insulin-induced hypoglycaemia. Urinary 17-OHCS were $3.9 \mathrm{mg}$ and urinary 17-ketosteroids $0.1 \mathrm{mg} / 24$ hours. Serum prolactin level was 16.4 